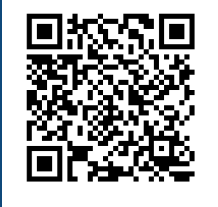

Keywords:

Chipboards

Medium density particleboard

Nanotechnology

Natural fiber

Urea formaldehyde

Historic:

Received 03/12/2018

Accepted 06/06/2019

Correspondence: ricardogam@gmail.com

Ricardo Gabriel de Almeida Mesquita ${ }^{1 a+}$, Anand Ramesh Sanadi ${ }^{2 a}$, José Manoel Marconcini ${ }^{3 a}$, Ana Carolina Correa ${ }^{3 b}$, Antônia Amanda da Silva César ${ }^{4 a}$, Láysa Maria Ferreira Andrade ${ }^{4 b}$, Thamirys Andrade Lopes ${ }^{5 a}$, José Alexandre Simão ${ }^{6 a}$, Lourival Marin Mendes ${ }^{4}$

\title{
THE EFFECT OF CELLULOSE NANOCRYSTALS IN SUGARCANE BAGASSE PARTICLEBOARDS OF PITH AND FIBERS
}

MESQUITA, R. G. A.; SANADI, A. R.; MARCONCINI, J. M.; CORREA, A. C.; CÉSAR, A. A. S.; ANDRADE, L. M. F.; LOPES, T. A.; SIMÃO, J. A.; MENDES, L. M. The effect of cellulose nanocrystals in sugarcane bagasse particleboards of pith and fibers. CERNE, v. 25 , n. 2, p.203-213, 2019 .

\section{HIGHLIGHTS}

The separation of pith and fiber did not affect the final properties of particleboards.

The NNCs inclusion did not affect the most properties.

Less links were available for SCB to interact with the adhesive.

Particleboards made only with fibers and without NCCs showed higher internal bond.

\section{ABSTRACT}

The aim of this research was to investigate sugarcane bagasse (SCB) particleboards, using two kinds of particles, from pith and fibers, reinforced with cellulose nanocrystals (NCC). The NCCs were dispersed in the adhesive urea formaldehyde (UF) using a sonificator in two proportions ( 0 and $1 \%$ ). The NCCs and UF were applied in the SCB particles using a rotary blender. The particleboards were produced in three layers using two kinds of particles: pith and fibers. After dispersion of the adhesive, the mixture was compressed to produce the particleboards, which were characterized by physical, mechanical and thermal properties. The anatomical and chemical features relating to pith and fiber were very similar. The particleboards made with and without NCCs did not differ statistically for most properties: modulus of elasticity (MOE), modulus of rupture (MOR), water absorption (WA) thermal conductivity (TC), and the volume heat capacity (VHC). Particleboards made only with fibers and without NCCs showed higher internal bond (IB). In the other hand particleboards made only with fibers in the face and pith in the core (without NCCs) showed lower thickness swelling after 24 hours (TS24h). Probably, the NCCs did not improve the particleboards performance, because less links were available for SCB to interact with the adhesive. For the others properties the particleboards made with pith and fibers did not showed statistical difference (MOE, MOR, TC, WA, TC and $\mathrm{VHC})$, demonstrating that separation of pith and fiber are not significant and does not affect the final properties of particleboards.

'Federal University of Southern Bahia, Itabuna, Bahia, Brazil - ORCID: 0000-0002-05 I3-5348a

2 University of Copenhagen Faculty of Science, Frederiksberg, Denmark - ORCID: 0000-0002-6382-9225

${ }^{3}$ Brazilian Agricultural Research Corporation, São Carlos, São Paulo, Brazil - ORCID: 0000-0002-04 19-9796ª 00000003-2472-4487

${ }^{4}$ Federal University of Lavras, Lavras, Minas Gerais, Brazil- ORCID: 0000-000I-5080-8807a, 0000-0002-9I28$4306^{\mathrm{b}}$

${ }^{5}$ Federal University of Viçosa, Viçosa, Minas Gerais, Brazil- ORCID: 0000-0002-2782-8604a 


\section{INTRODUCTION}

Sugarcane bagasse (SCB) is a residue of lignocellulosic fiber derived from sugarcane processing and juice extraction. It is used in the sugar and ethanol industry to generate heat, steam and energy. Sugarcane acreage and industrialization has been increasingly in the last years, therefore also the SCB amount (DEA, 2013; Driemeier et al., 201 I; Fiorelli et al., 20II; Rasul et al., 1999; UNICA, 2017). The chemical composition of SCB varies according to several factors, such as type of cane, soil type and harvesting techniques. Cellulose content, lignin and polyoses in the pith (not fiber fraction) and the fibers closely resemble each other as well as hardwoods (Hemmasi et al., 20I I). However, pith and true fibers are different in morphological functions and concerning their liquid absorption capacities (Driemeier et al., 20II; Lee and Mariatti, 2008; Martinez et al., 1997; Widyorini et al., 2005).

The total area harvested in Brazil in the 2017/2018 harvest was 8.7 million hectares. The Brazilian sugar and ethanol industry processed 636 million tons of sugarcane. Ethanol production was 27.7 billion liters and sugar was 38. I million tons. In relation to the biomass, plants the sugarcane bagasse was the most used fuel in the biomass thermal generation. In 2017, the share of sugarcane in the national energy generation was 3.6\% (MME, 20I8). The volume of bagasse from the sugarcane harvest in Brazil (2013) was $174320 \times 10^{3}$ tons (DEA, 2013) and increased to $180814 \times 10^{3}$ tons in 2015 (DEA, 2016). The magnitude of such a volume and its availability contributes to increasing interest in this waste by product.

Researchers have been studying new applications for SCB, and trying to bring about changes in a residue by product to create new products with more added value, such as composites (Loh et al., 2013; Mesquita et al., 20।8; Oliveira et al., 2016b), and one example of these composites is the particleboard (Lee et al., 2006; Widyorini et al., 2005). Particleboards are normally produced with elements of the breakdown of wood (particles/chips), which are later combined with adhesive bonding under pressure and high temperature (Iwakiri, 2005; Kelly, 1977; Maloney, 1996). They can be produced in single layers (chipboards) or in three layers (medium density particleboards - MDP). Regarding the raw material wood is the most used, although, any lignocellulosic material can be used for the particleboard production, such as SCB (Carvajal et al., 1996; Guler et al., 2016; Han et al., 2005; Hazrati-Behnagh et al., 2016; Jonoobi et al., 2016; Khazaeian et al., 2015; Lee et al., 2006; Mesquita et al., 2018; Oliveira et al., 2016a; Rangavar et al., 2016). One advantage of SCB is that, it can be easily converted into sliver particles, similarly as with wood (Driemeier et al., 20I I; Garzón-Barrero et al., 2016; Hemmasi et al., 20I I; Lee et al., 2006; Wu, 200I).

Due the chemical composition and the mechanical processing, SCB has some drawbacks such as: high water absorption (WA) (Lee and Mariatti, 2008; Xu et al., 2009); high amounts of ash and extractives that can affect the adhesive cure and the adherence between particles and adhesive (Widyorini et al., 2005; Xu et al., 2009); and, fibers (cells) with less stiffness and more damaged because of the sugarcane milling process (Guimarães Júnior et al., 2012; Mesquita et al., 2017). New studies have been done trying to overcome those problems.

Nanotechnology has been applied in adhesives, particleboards and composites to overcome the lignocellulosic drawbacks and to improve their properties (Candan and Akbulut, 2013; Kumar et al., 2013; Liu and Zhu, 20I4; Marzbani et al., 20I5; Salari et al., 20I2; Salari et al., 2013). The incorporation of nanofibers and nanocrystals from cellulose has shown to be very promising since the particleboards have shown better performance (Atta-Obeng et al., 2012; Veigel et al., 2012; Zhang et al., 20II; Zorba et al., 2008). Better mechanical properties performance (internal bond and modulus of rupture) of particleboards reinforced with nanocellulose (CNF) and microfibrillated cellulose (MFC) were found by (Mahrdt et al., 20I6; Veigel et al., 20I2), and also better performance in physical properties (thickness swelling) by (Veigel et al., 20I2). Leng et al. (20I7a) got higher bending strength in particleboard with CNF addition and Leng et al. (20I7b) better performance for water absorption using at least I5\% of CNF in particleboard produced with large particles.

Thus, the aim of this research was to produce and investigate the effects of cellulose nanocrystals (NCC) inclusion in particleboards made with pith and fiber particles.

\section{MATERIAL AND METHODS}

\section{Raw material and raw material characterization}

Urea formaldehyde adhesive (UF), NCC freeze dried, and SCB particles were used to produce the particleboards. Sugarcane bagasse particles were separated in two materials: pith and fibers.

The adhesive solid content was measured by drying I $\mathrm{g}$ of adhesive during 4 hours in an oven at $105^{\circ} \mathrm{C}$. The $\mathrm{pH}$ was measured using a $\mathrm{pH}$ meter and the viscosity was measured using a Brookfield viscometer.

The sugar cane bagasse (SCB) was from São Paulo State, Brazil, kindly donated by Edra Ecossitemas Ltda. 
The length, width, and lumen diameter of the individual cells from fibers and pith were performed with the aid of Olympus BX4I microscope, using Wincel Regent PRO software. Each of the morphological features was measured in at least 30 fibers. To separate the particles in individual fibers the samples passed through maceration process. Anatomical terms describing the fibers were used as recommended by the International Association of Wood Anatomists -IAWA (Wheeler et al., 1989). The flexibility coefficient (FC) and wall fraction (WF) parameters were calculated for individual fibers (De Paula and da Silva Junior, 1994; de Paula, 1993; Fonseca et al., 2013). The FC was calculated by the ratio between the fiber lumen diameter and the fiber cell diameter, expressed in percentage. The WF was calculated by the ratio between cell wall thickness and fiber cell diameter, expressed as a percentage. The pith and fiber particles had the chemical analysis measured according to the (TAPPI, 20II).

The NCC freeze-dried were purchased from University of Maine - EUA. Transmission electron microscope was used to take TEM images from NCC.

\section{Cellulose nanocrystals dispersion}

The NCCs were dispersed directly in the adhesive (UF). It used 0 and $1 \%$ of NCC (by adhesive mass, including the water). The NCCs were placed in $100 \mathrm{~g}$ of adhesive and sonicated twice during 3 minutes each time. The samples were run at $60 \%$ amplitude and the beaker was partially immersed in an ice bath to avoid that the samples get overheated (Figure I). The time was chosen through visual observation of the turbidity of the resulting suspension. After the dispersion, the adhesive had a Brookfield viscosity measured at $30^{\circ} \mathrm{C}$.

\section{Particleboards production}

The SCB was separated in two materials: pith and fiber. The separation was made by density difference using vibrating sieves. Later on, the SCB was passed through the hammer mill to generate the sliver particles and, subsequently,

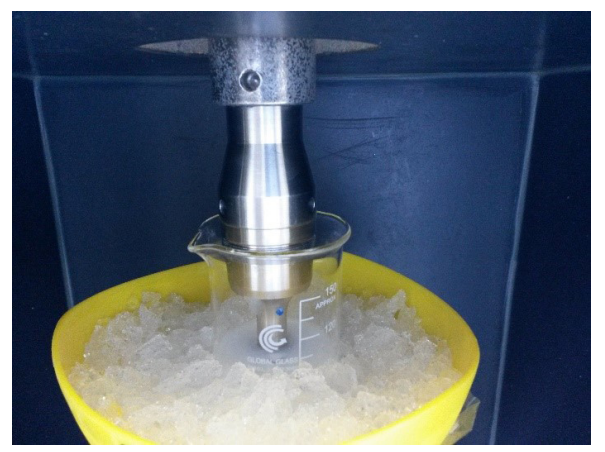

FIGURE I Beaker immerse in ice for NCC dispersion using a Branson digital sonifier. they were classified in sieves of 14,20 and 120 mesh. The particles retained in the sieves of 120 and 20 mesh were used for the faces and cores, respectively (particleboards in 3 layers). The particles were dried in an oven at $90^{\circ} \mathrm{C}$ until they achieved a final moisture content of $4 \%$.

The adhesive was spread using a rotary blender in two steps. Initially, the adhesive was applied to smaller particles (for the two faces) in a proportion of $12 \%$ (dry basis mass of the particles). Later on, the bigger particles (for the core) were coated with the adhesive in a proportion of $10 \%$ (dry basis mass of the particles). Due to the higher surface area to volume, more adhesive was used for the smaller particles to guarantee good adhesion. For each treatment, three particleboards were produced with a nominal density of $0.650 \mathrm{~g} . \mathrm{cm}^{-3}$. The proportion used in the three layers (face/core/face) was 20/60/20 (basis of mass particles), respectively. The adhesive reinforced with NCC was used only in the faces, and all the faces were produced only with fibers (Table I). The particleboards produced were compared with commercial SCB particleboards from China.

TABLE I Treatments and their compositions.

\begin{tabular}{ccc}
\hline & \multicolumn{2}{c}{ Materials used in the particleboard layers } \\
\cline { 2 - 3 } Treatments & $\begin{array}{c}\text { Face (20\%) - small particles } \\
\text { (basis of mass particles) }\end{array}$ & $\begin{array}{c}\text { Core (60\%) - big particles } \\
\text { (basis of mass particles) }\end{array}$ \\
\hline Commercial & - & - \\
Pith-0 & Fibers & Pith \\
Pith-I & Fibers + I\% NCC & Pith \\
Fiber-0 & Fibers & Fibers \\
Fiber-I & Fibers + I\% NCC & Fibers \\
\hline
\end{tabular}

To decrease the mattress thickness, the particle mattress was pre-pressing in a hydraulic press at 0.78 $\mathrm{MPa}$ of pressure. Later on, it was transferred to a hot press machine $\left(3.92 \mathrm{MPa}\right.$ of pressure, at $160^{\circ} \mathrm{C}$, during 8 minutes) (Figure 2).

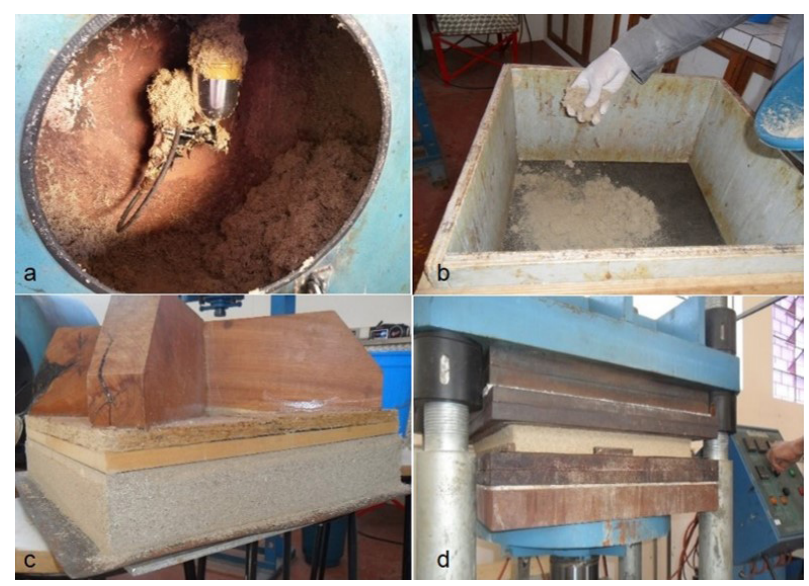

FIGURE 2 Particleboard production. Adhesive dispersion (a), particle mattress formation (b), mattress after pre pressing (c) and hot pressing (d). 
After the hot pressing and subsequent cooling, at room temperature, the edges of the boards were trimmed, resulting in final dimensions of $30 \times 30 \times 1.5 \mathrm{~cm}$. The boards followed to controlled chamber $\left(22 \pm 2^{\circ} \mathrm{C}\right.$ and $65 \pm 5 \%$ of moisture) for acclimatization until constant mass was achieved before of properties characterization (Figure 3).

\section{Particleboards characterization}

Particleboards were evaluated by measuring their physical, mechanical and thermal properties by using standardized tests: the density was evaluated according to (EN-323, 1993), using 5 samples per treatment; the WA after 2 hours (WA2h), WA after 24 hours (WA24h), thickness swelling after 2 hours (TS2h), and thickness swelling after 24 hours (TS24h) of immersion in water according the (EN-317, 1993), using 12 samples per treatment; the modulus of elasticity (MOE), modulus of rupture (MOR), and internal bond (IB) according the ASTM DIO37 (ASTM, 2006) using an EMIC DL 3000 universal testing machine. Six samples were used for MOE and MOE per treatment and I5 samples for IB.

Thermal properties were measured in an equipment ISOMET model 2104 . The samples with $6 \times 6 \times 1.5 \mathrm{~cm}$ were placed in a controlled chamber $\left(20^{\circ} \mathrm{C}\right.$ and $65 \%$ of moisture) until constant mass before being tested. Five samples were measured for each treatment.

The data were analyzed as a completely randomized design. It was made an analysis of variance (ANOVA) and when significant the Scott-Knott ( $p$ $<0.05 \%$ ) test average. The results were processed with the aid of SISVAR software.

\section{RESULTS AND DISCUSSION}

\section{Urea formaldehyde adhesive characteristics}

UF in the liquid state showed $54 \%$ of solids contents, 7.94 of $\mathrm{pH}$ and 0.127 Pa.s. of viscosity (at $30^{\circ} \mathrm{C}$ ). The viscosity of the adhesive increased with the NCC inclusion, from 0.127 to 0.162 Pa.s. More details about the UF adhesive characteristics can be found in a previous work (Mesquita et al., 2018).

\section{Cellulose nanocrystals characteristics}

The University of Maine provide some NCCs specifications: $98 \mathrm{w} / \%$ (solids); 5-20 nm wide and I 50-200 $\mathrm{nm}$ long (fiber dimensions); $1.5 \mathrm{~g} \cdot \mathrm{cm}^{-3}$ (density): white and odorless (appearance); and hydrophilic (surface property). Considering the mean length of $175 \mathrm{~nm}$ and the mean diameter of $12.5 \mathrm{~nm}$ the aspect ratio (length/diameter) is 14. The Figure 4 shows the TEM images of the cellulose nanocrystals. The shape of nanomaterial can be different: spherical particles, platelets and fiber (such as nanofiber from cellulose) and the high aspect ratio is believed to be very influential in reinforcing mechanisms (Fufa et al., 2012; Marathe and Kantak, 2008; Nikolic et al., 20I5). The nanocrystallie cellulose (NCCs) are from chemical process that result in a purely crystalline structure (Do Prodo et al., 20 I8; Filson et al., 2009; Kaboorani et al., 20I2). They are different from nanofibrils from mechanical process that result in crystalline and amorphous regions (Tonoli et al., 2012; Veigal et al., 2012). More details about the NCC characteristics and its interaction with the urea formaldehyde resin can be found in a previous work (Mesquita et al., 20I8). In that previous work, the research was focused on the interaction of the same NCC with the same resin used in the present research.

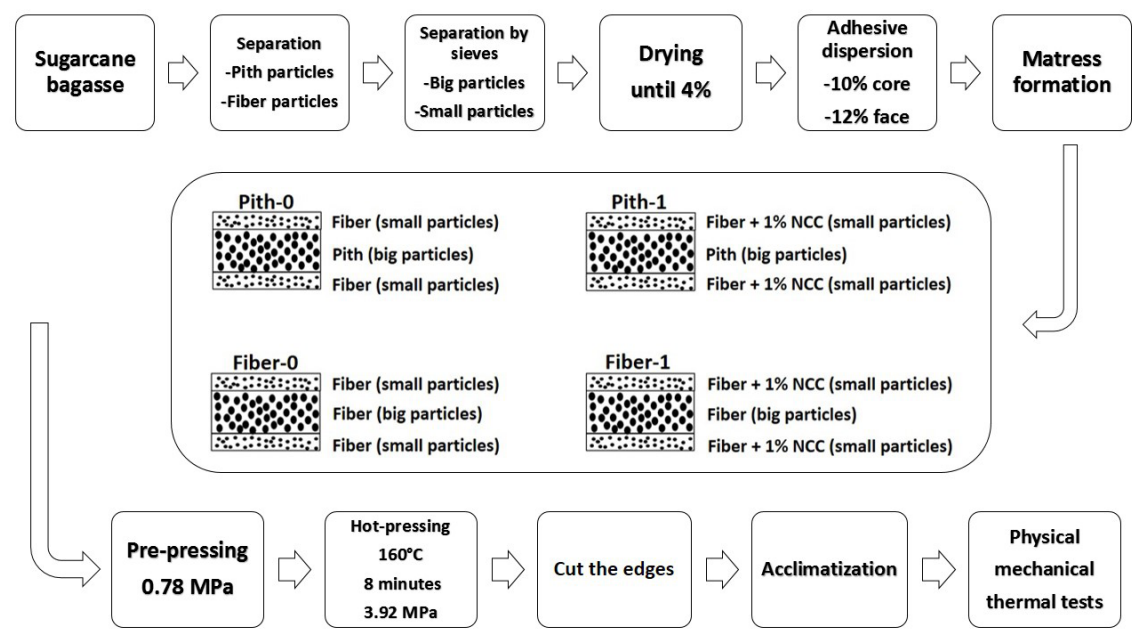

FIGURE 3 llustrate scheme of particleboard production. 


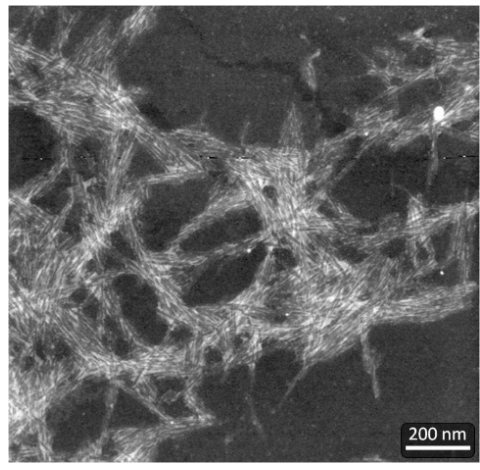

FIGURE 4 TEM micrograph of NCC.

\section{Pith and fiber characteristics}

The anatomical characteristics did not differ for all characteristics (Table 2). The values of the fiber cell length and diameter are in agreement with the literature, and the SCB has intermediate values between Eucalyptus and Pine wood (Hemmasi et al., 20l I; Mesquita et al., 20I7). Hemmasi et al. (20II) measured just fibers and found similar mean values: I590 $\mu \mathrm{m}$ (length), $20.96 \mu \mathrm{m}$ (cell diameter), 5,64 $\mu \mathrm{m}$ (wall thickness) and $9.72 \mu \mathrm{m}$ (lumen width).The cell wall fraction is related to the rigidity of the cell and values above $60 \%$ are normally related to stiffer fibers (Guimarães Junior et al., 20l0). However, the values of fibers and pith were very similar, close to $40 \%$.

TABLE 2 Anatomical analysis.

\begin{tabular}{ccc}
\hline Anatomical characteristics & Fiber & Pith \\
\hline Length $(\mu \mathrm{m})$ & $\mathrm{I} 12.33 \mathrm{a}$ & $\mathrm{I} 474.3 \mathrm{I} \mathrm{a}$ \\
Cell diameter $(\mu \mathrm{m})$ & $20.38 \mathrm{a}$ & $19.41 \mathrm{a}$ \\
Lumen diameter $(\mu \mathrm{m})$ & $12.34 \mathrm{a}$ & $11.06 \mathrm{a}$ \\
Cell wall thickness $(\mu \mathrm{m})$ & $4.02 \mathrm{a}$ & $4.17 \mathrm{a}$ \\
Flexibility coefficient $(\%)$ & $58.13 \mathrm{a}$ & $54.62 \mathrm{a}$ \\
Cell wall fraction $(\%)$ & $41.86 \mathrm{a}$ & $45.37 \mathrm{a}$ \\
\hline
\end{tabular}

Same letters in the line indicate that there is no statistical difference by Scott Knott test $(\alpha=0.05)$

Driemeier et al. (20I I) classified particles (from pith and rind) in four sieves $(4,0.85,0.6$, and $0.15 \mathrm{~mm})$. They classified as rind those particles that were retained in the three first sieves, and the last one as a mix of fibers and pith. Those particles that passed through the $0.15 \mathrm{~mm}$ sieve were classified as pith. However, they observed the presence of fibrous particles in all powders, including the pith fraction. They explain that it is related to the limitation of sieves to hold fibrous particles, which may pass sieves longitudinally. In this present work, it was also possible to find true fiber in the pith particles.

The pith showed a higher amount of lignin, and the fibers showed a higher amount of cellulose, extractives and ash (Table 3). The pith and fibers did not show high amounts of extractives, and this can be explained by the method of sugarcane processing that can extract some part of the extractives. These results are in agreement to those found in the literature (Hemmasi et al., 20I I).
TABLE 3 Chemical composition of pith and fiber.

\begin{tabular}{ccc}
\hline Chemical composition & Fiber (\%) & Pith (\%) \\
\hline Cellulose & $57.33 \mathrm{a}$ & $53.9 \mathrm{~b}$ \\
Hemicellulose & $17.10 \mathrm{a}$ & $17.2 \mathrm{a}$ \\
Lignin soluble & $0.76 \mathrm{a}$ & $0.39 \mathrm{~b}$ \\
Lignin insoluble & $24.63 \mathrm{~b}$ & $26.4 \mathrm{a}$ \\
Extractives & $1.24 \mathrm{a}$ & $1.11 \mathrm{~b}$ \\
Ash & $1.18 \mathrm{a}$ & $0.82 \mathrm{~b}$ \\
\hline
\end{tabular}

Same letters in the line indicate that there is no statistical difference by Scott Knott test $(\alpha=0.05)$.

\section{Physical and Mechanical Properties}

\section{Density and Internal Bond}

Most of the properties are directly affected by density and moisture, because of this, they are important properties that ensure fairness among treatments, thus allowing comparing the average values of physical and mechanical properties. According to Iwakiri (2005) all the particleboards were classified as medium density (density between 0.59 and $0.80 \mathrm{~g} \cdot \mathrm{cm}^{-3}$ ). The moisture ranged from 8.5 to $9.0 \%$. Both those properties showed a slight variation of the mean values, except the commercial boards from China, which showed higher density (Figure 5).

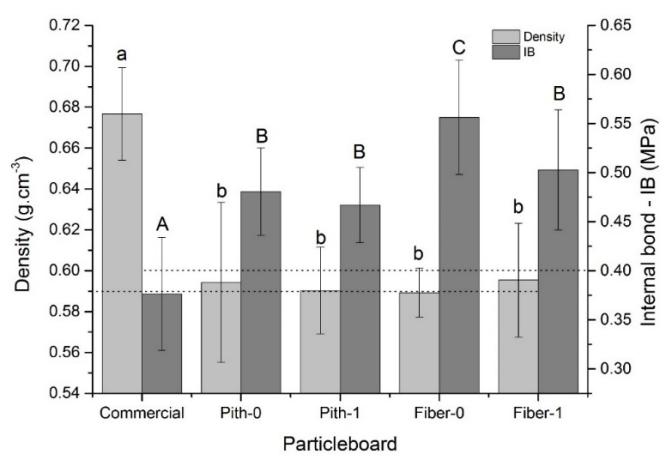

FIGURE 5 Histogram of the mean values for density, and internal bond (IB). Bars indicate standard deviation. Lines indicate minimum values for medium density particleboards and minimum standard values for IB. Same letters indicate that there is no statistical difference by Scott Knott test ( $\alpha=0.05)$.

All treatments showed best performances for IB, than the commercial SCB particleboards from China. The particleboards made only with fibers showed high mean values than those made with pith. The inclusion of NCC decreased the mean values for boards made only with fibers. Hydroxyls NCC groups probably react faster with UF leaving less available reacting groups for the SCB particles, which could explain the worst performance of Fiber-I. The NCCs inclusion increase the viscosity and this can hinder the adhesive penetration in the cell wall or voids, leading to less hooks formation. Considering that 
all the effects of distribution, dispersion and viscosity of the adhesive are very low, the reactivity between NCC and UF could dominate the process. One suggestion is to increase the relative concentration of functional groups in the formulation of the adhesive, to compensate this reaction effect with the NCC.

The fibers and pith of both materials were classified according to sieve sizes however, after passing through the sieves it was possible to see that the particles from pith were smaller than from fibers. This means that they have more surface area for the adhesive cover, which could explain the lower mean values for particleboards made with pith in the core. According to Driemeier et al. (20II) for the non-spherical particles, the smaller projections are of the dimension effectively controlled by sieves.

Mahrdt et al. (2016) investigated the effects of MFC addition in particleboards. The MFC was mixed with UF in two proportions ( 0 and $5 \%$ ), and they found different results. The MFC inclusion increased the IB mean values of the particleboards (30\% more). The better performance for IB was attributed to the distribution of the adhesive, because a higher fraction of adhesive + MFC was available for bond-line formation, and a larger part of the wooden particles could be covered with the adhesive.

Widyorini et al. (2005) studied binderless particleboards made of pith and fibers. They found that bagasse pith particles provided better IB than rind particles. According to them, bagasse pith particles were more easily deformed than bagasse rind particles, enlarging the bonding contact area.

The ANSI A208.I (ANS, 1993) provides minimum IB values of $0.40 \mathrm{MPa}$ for UF adhesive (MI class). All particleboards meet the minimum requirements, except the commercial boards from China.

\section{Modulus of elasticity (MOE) and modulus of rupture (MOR)}

The best performances for MOE and MOR were found for commercial boards (Figure 6). The NCC inclusion did not affected the MOE and MOR, since the particleboards with NCC inclusion were statistically equal to those without NCC. No statistical difference were observed among the particleboards made with pith and fiber for MOR and MOE.

It was possible to see that commercial particleboards used longer particles, which can explain the best performance for the mechanical properties. The sliver particles were not measured, although,

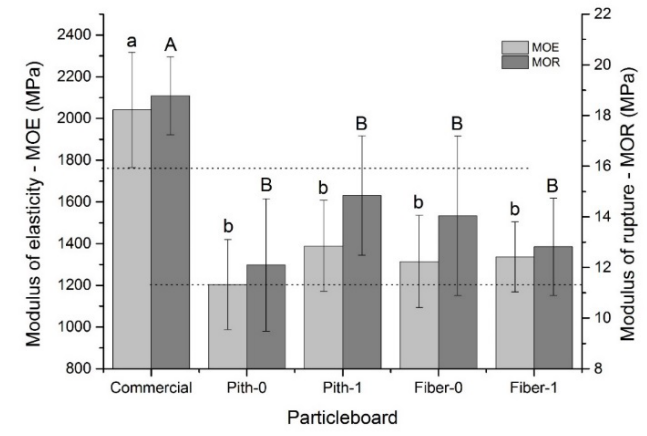

FIGURE 6 Histogram of the mean values for MOE, and MOR. Bars indicate standard deviation. Lines indicate minimum standard values for MOE and MOR. Same letters indicate that there is no statistical difference by Scott Knott test $(\alpha=0.05)$.

it was clearly visible that the length of the particles from commercial particleboards were longer than the particles used in the present work (Figure 7). Increasing the length, it is possible to increase the slenderness ratio (length/thickness). Higher slenderness ratio increases the bending properties (Iwakiri, 2005; Lee et al., 2006). Associate to this, the commercial particleboards showed higher density, which is directly related with the mechanical properties ( $\mathrm{Wu}, 200 \mathrm{I})$.

Widyorini et al. (2005) studied binderless particleboards made of pith and fibers. They found that bagasse pith particles provided better board properties (MOE and MOR) than rind particles. According to them, bagasse pith particles were more easily deformed than bagasse rind particles, enlarging the bonding contact area. They also found no difference for TS.

Lee and Mariatti (2008) studied the addition of particles from pith and fibers in polyester composites. The composites using particle fibers had shown better mechanical (MOE and MOR) and physical properties (WA) than those made with pith particles.

Leng et al. (2017a) found higher MOE and MOR in particleboard with CNF addition, however they used wood to produce the particleboard and this variable (CNF) interacted with others, such as density and particle size.

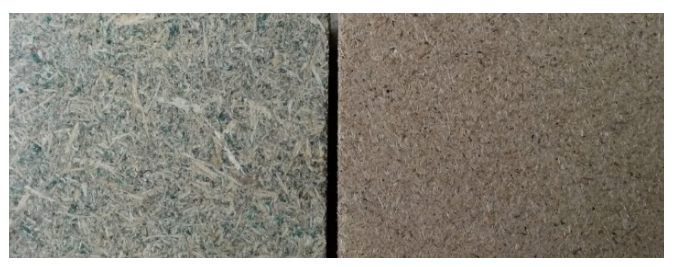

FIGURE 7 Commercial SCB particleboards from China with longer particles (in the right) and SCB particleboards made in the present work (in the left). 
ANSI A208.I (ANS, 1993) stipulates the average minimum values of $1764 \mathrm{MPa}$ for $\mathrm{MOE}$ and 11.3 for MOR, for particleboards/chipboards made with urea formaldehyde (class MI). Just the commercial boards meet the minimum requirements for $\mathrm{MOE}$, although all particleboards meet the minimum requirements for MOR.

Atta-Obeng et al. (20I2) studied the effect of MCC inclusion in particleboards made with two species: sweetgum and pine. The MCC was applied in PF adhesive in two proportions: 0 and $10 \%$. The MCC inclusion had a negative effect in the particleboards mechanical properties (MOE and MOR), decreasing the mean values. Probably the mechanical properties decreased because it used a high amount of MCC, which could agglomerate and harm the dispersion that affecting the properties of the particleboards. The surface area could also be related to this effect. Similar with this study, the MCC can react preferentially with the PF due the higher surface area, decreasing the sites for particles bond.

Veigel et al. (20I2) investigated the effect of cellulose nanofibrils (CNF) inclusion in particleboards. They applied the CNF in the UF using different proportions (0, I and 3\%). Better mechanical performance (MOR and IB) was found using $1 \%$ of CNF however, using $3 \%$ of CNF showed lower mean values than the control. The author suggested that this lower mean values using $3 \%$, was not directly induced by higher CNF content, but could be explained by the long cold drying time ( 12 hours) of the glue and wood particles prior to hot pressing.

Water absorption (WA) and thickness swelling (TS)

The commercial boards from China showed the lowest mean values for WA2h and WA24h (Figure 8). As mentioned before, the particles of China particleboards were higher, which decrease the superficial area and offer less site for hydrogen bonds between water and fibers. The adhesive type and the adhesive proportion have a huge influence in these properties however, there is no information about the adhesive (kind and proportion) used in those SCB particleboards from China.

The NCC inclusion did not affect these properties (WA2h and WA24h), neither the materials (pith and fiber).

The aminomethylene linkage present in the UF adhesives is susceptible to hydrolysis, which means that the UF has low water and weather resistance. This explain the higher WA of particleboards made with UF. The water can cause swelling, which can induce a movement of the structural components of the MDP, breaking the bonding among resin and wood surface sites due to mechanical forces and stresses (Dunky, 1998; Dunky, 2004; Liu et al., 2008), creating more voids for water

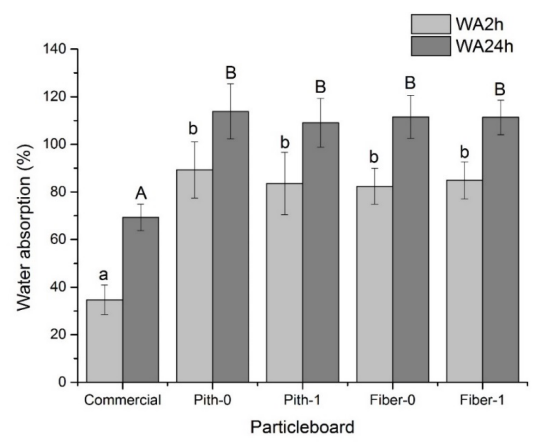

FIGURE 8 Histogram of the mean values for the water absorption after 2 hours (WA2h) and water absorption after 24 hours (WA24h). Bars indicate standard deviation. Same letters indicate that there is no statistical difference by Scott Knott test $(\alpha=0.05)$.

entrance. Nevertheless, UF is still used for particleboard production because it is indicate for internal purposes. Furthermore, it is easy to manipulate and it is cheaper when compared with others adhesives, as PF.

The commercial boards from China showed the lowest mean values for TS2h and TS24h (Figure 9). The NCC inclusion increased the TS24h for pithI. No effect was found with NCC inclusion for TS2h for both materials (pith and fiber). Pith and fiber showed similar amounts of hemicellulose, which could offer more hydroxyls groups for water sorption, but cellulose content also plays as a major role (Mohanty et al., 2000). Thus, materials with more cellulose tends to show higher dimension instability, because the water can enter between the cellulose chains causing their distancing and swelling. The particleboards made with pith showed higher dimension stability because the pith particles showed less cellulose and higher amount of lignin that it is hydrophobic.

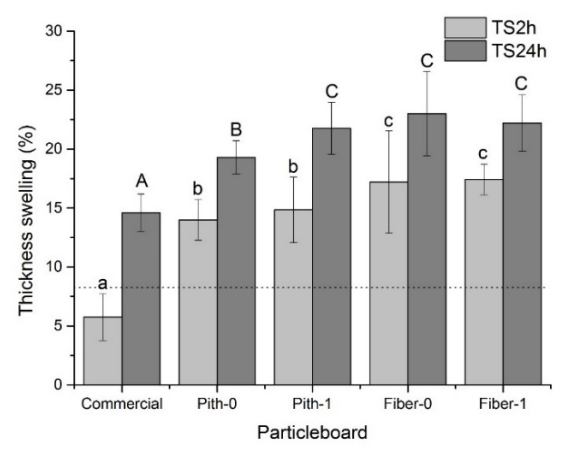

FIGURE 9 Histogram of the mean values for the thickness swelling after 2 hours (TS2h), thickness swelling after 24 hours (TS24h). Bars indicate standard deviation. Line indicates maximum standard values for TS24h. Same letters indicate that there is no statistical difference by Scott Knott test $(\alpha=0.05)$. 
Doost-hoseini et al. (20/4) studied SCB particleboards with $0.5 \mathrm{~g} . \mathrm{cm}^{-3}$ of density and found higher mean values for WA2h (110\%), WA24h (140\%), and similar results for TS2h (16\%) and TS24h (19\%). Since they used a similar adhesive proportion (I2\%) probably the WA was higher due the lower density, which means more voids, where the water could enter. Atta-Obeng et al. (20/2) studied the effect of MCC inclusion in particleboards made with two species: sweetgum and pine. The MCC was applied in PF adhesive in two proportions: 0 and 10\%. The MCC inclusion had a negative effect in the particleboards properties (TS2h and TS24h), increasing the mean values. The authors, attributed this to more available hydroxyl groups for moisture sorption, and consequent thickness swelling, caused by MCC inclusion.

Veigel et al. (20I2) investigated the effect of cellulose nanofibrils (CNF) inclusion in particleboards. They applied the CNF in the UF using different proportions (0, I and $3 \%)$. The TS mean value, decreased with $1 \%$ CNF inclusion however, with $3 \%$ of CNF increased and the mean value was higher than the control.

The ANSI A208.I (ANS, 1993) establishes maximum values for only TS24h, that is $8 \%$ for chipboards produced with urea formaldehyde. Therefore, none of the MDPs produced showed lower values stipulated by the standard.

\section{Thermal properties}

The thermal conductivity (TC) and volume heat capacity $(\mathrm{VCH})$ showed higher values for SCB particleboards from China (Figure 10). This can be explained by the density of those boards that were higher than the density of the particleboards produced in the present work (Bekhta and Dobrowolska, 2006).

The inclusion of NCC did not affected the TC and the $\mathrm{VHC}$, neither the kind of material (pith and fiber). The particleboards produced in this work were statistically equal.

The relationships between TC and density were also observed by others authors: Bekhta and Dobrowolska (2006) when evaluating the properties of wood-gypsum boards; Sampathrajan et al. (1992), studying properties of boards made from farm residues and Mesquita et al. (2016) studying wood particleboards with coir and sisal inclusion.

The TC is important property, especially when the particleboards will be used for insulator purpose. TC is an indicator of the value of a material as a heat insulator and lower TC is indicate for thermal insulation (Khedari et al., 2004).

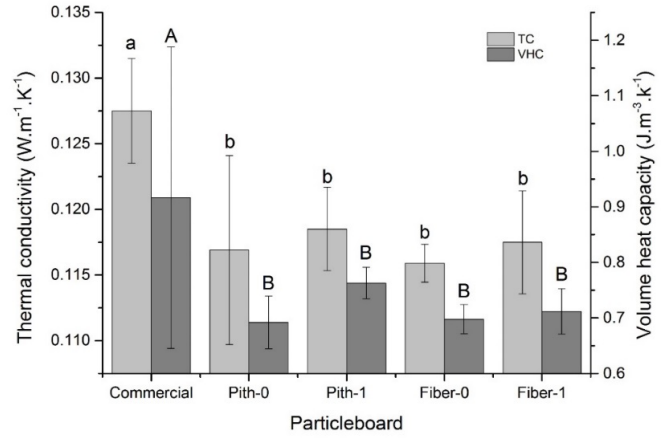

FIGURE IOHistogram of the mean values for the thermal conductivity (TC) and volume heat capacity (VHC). Bars indicate standard deviation. Same letters indicate that there is no statistical difference by Scott Knott test $(\alpha=0.05)$.

\section{CONCLUSIONS}

In this research, MDP panels using sugar cane bagasse were produced. The particles were separate in fibers and pith to be used in the layers of the panels. In addition, the effect of the inclusion of cellulose nanocrystals on the urea formaldehyde adhesive was evaluated. The quality of the panels was evaluated by physical and mechanical properties.

The sugarcane bagasse particles can be used to produce particleboards for internal purposes. It was found that the separation in pith and fibers does not seem efficient, since the MDP properties of both were very similar. In addition, the two kinds of material showed very similar anatomical and chemical properties.

The particleboards produced in this study showed worst performance for mechanical (MOE and MOR) and physical (TS and WA) properties when compared with commercial SCB particleboards from China. Probably due the higher density of commercial particleboards.

The NCC inclusion in the faces of the particleboards did not showed efficient, since for most properties the particleboards with and without NCC were statistically equal. Probably less site links were available for the SCB to interact with the adhesive and because the NCCs increased the adhesive viscosity, this could make adhesive penetration more difficult.

\section{REFERENCES}

ANS (1993). Mat-formed wood particleboard: Specification ANSI/A 208. I. Gaithersburg.

ASTM (2006). Standard methods of evaluating properties of wood-base fiber and particles materials, ASTM D-I03706a. Philladelphia.

ATTA-OBENG, E.; VIA, B.K.; FASINA, O. Effect of microcrystalline cellulose, species, and particle size on mechanical and physical properties of particleboards. Wood and Fiber Science, v.44, p. I-9, 2012. 
BEKHTA, P.; DOBROWOLSKA, E. Thermal properties of wood-gypsum boards. Holz als Roh-und Werkstoff, v.64, n.5, p.427-428, 2006.

CANDAN, Z.; AKBULUT, T. Developing environmentally friendly wood composite panels by nanotechnology. BioResources, v.8, n.3, p.3590-3598, 2013.

CARVAJAL, O.; VALDÉS, J.; PUIG, J. Bagasse particleboards for building purpose. Holz als Roh-und Werkstoff, v.54, n. I, p.6I-63, 1996.

DE PAULA, J.; DA SILVA JUNIOR, F. Anatomical study of native woods suitable for energy and paper production. Pesquisa Agropecuaria Brasileira, v.29, n. 12, p.1807-1821, 1994.

DE PAULA, J.E. Madeiras da caatinga úteis para produção de energia. Pesquisa Agropecuária Brasileira, v.28, n.2, p.153-165, 1993.

DEA (20I3). BOLETIM DE CONJUNTURA ENEGÉTICA. Bagaço de cana, Nota técnica DEA 23/I3. Brazil

DEA (20I6). BOLETIM DE CONJUNTURA ENERGÉTICA. BAGAÇO DE CANA, Nota técnica 38/I6. Brazil

DOOST-HOSEINI, K.; TAGHIYARI, H.R.; ELYASI, A. Correlation between sound absorption coefficients with physical and mechanical properties of insulation boards made from sugar cane bagasse. Composites Part B: Engineering, v.58, p.10-15, 2014.

DO PRODO, N.R.; RAABE, J.; MIRMEHDI, S.; HUGEN, L.N.; LIMA, L.C.; RAMOS, A.L.S. GUIMARÃES JÚNIOR, M.; TONOLI, G.H.D. Strength improvement of hydroxypropyl methycellulose/strach films using cellulose nanocrystals. Cerne, v.23, n.4, p.423-434, 2018.

DRIEMEIER, C.; OLIVEIRA, M.M.; MENDES, F.M.; GÓMEZ, E.O. Characterization of sugarcane bagasse powders. Powder technology, v.2।4, n. I, p.III-I I6, 20 II.

DUNKY, M. Urea-formaldehyde (UF) adhesive resins for wood. International Journal of Adhesion and Adhesives, v. 18 n.2, p.95-107, 1998.

DUNKY, M. Adhesives based on formaldehyde condensation resins. In: Macromolecular Symposia, 2004. vol I. Wiley Online Library, p. 4I7-430, 2004.

EN-3I7 (1993). Particleboards and fibreboards Determination of swelling in thickness after immersion in water, EN 317.

EN-323 ES (1993). Wood-based panels - Determination of density vol EN - 323.

FILSON, P.B.; DAWSON-ANDOH, B.E.; SCHWEGLERBERRY, D. Enzymatic-mediated production of cellulose nanocrystals from recycled pulp. Green Chemistry, v. I I, n. II, p. I808-I8I4, 2009.
FIORELLI, J.; LAHAR, F.A.R.; DO NASCIMENTO, M.F.; JUNIOR, H.S.; ROSSIGNOLO, J.A . Painéis de partículas à base de bagaço de cana e resina de mamona-produção e propriedades. Acta Scientiarum Technology, v.33, n.4, p.40I-406, 20 II.

FONSECA, A.; MORI, F.; TONOLI, G.; SAVASTANO, H.; FERRARI, D.; MIRANDA, I. Properties of an Amazonian vegetable fiber as a potential reinforcing material. Industrial Crops and Products, v.47, p.43-50, 2013.

FUFA, S.M.; JELLE, B.P.; HOVD, P.J. RORVIK, P.M. Impregnated wooden claddings and the influence of nanoparticles on the weathering performance. Wood Materials Science \& Engineering, v.7, n.4, p.186-195, 2012

GARZÓN-BARRERO, N.M.; SHIRAKAWA, M.A.; BRAZOLIN, S.; DE BARROS PEREIRA, R.G.D.F.N.; DE LARA, I.A.R.; SAVASTANO JR, $\mathrm{H}$. Evaluation of mold growth on sugarcane bagasse particleboards in natural exposure and in accelerated test. International Biodeterioration \& Biodegradation, v. I I5, p.266-276, 2016.

GUIMARÃES JÚNIOR, M.; NOVACK, K.M.; BOTARO, V.R.; PROTÁSIO, T.D.P. Caracterização de polpas de bambu modificadas quimicamente visando melhorias em suas interações interfaciais para aplicações em compósitos. Revista Iberoamericana de Polímeros, v.|3, p.89102, 2012.

GUIMARÃES JUNIOR. M.; NOVACK, K.M.; BOTARO, V.R. Caracterização anatômica da fibra de bambu (Bambusa vulgaris) visando sua utilização em compósitos poliméricos. Revista Iberoamericana de Polímeros, v. I I, n.7, p.442456, 2010.

GULER, C.; SAHIN, H.I.; YENIAY, S. The potential for using corn stalks as a raw material for production particleboard with industrial wood chips. Wood Research, v.6I, n.2, p.299-306, 2016.

HAN, G.; WU, Q.; VLOSKY, R. Physical and Mechanical Properties of Sugarcane Rind and Mixed Hardwood Oriented Strandboard Bonded with PF Resin. Forest Products Journal, v.55, n. I0, p.28-36, 2005.

HAZRATI-BEHNAGH, M.; ZAREA-HOSSEINABADI, H.; DALIRI-SOSEFI, M.; ABGINEHCHI, Z.; HEMMATI, A. Mechanical and insulating performances of ultralight thick particleboard from sugarcane residues and woods planer shaving. European Journal of Wood and Wood Products, v.74, n.2, p.161-168, 2016.

HEMMASI, A.H.; SAMARIHA, A.; TABEI, A.; NEMATI, M.; KHAKIFIROOZ, A. Study of morphological and chemical composition of fibers from Iranian sugarcane bagasse. American-Eurasian Journal Agricultural \& Environmental Sciences, v. I I, n.4, p.478-48I, 20 I I.

IWAKIRI, S. Painéis de madeira reconstituída. Curitiba: FUPEF, 2005. 247 p. 
JONOOBI, M.; GRAMI, M.; ASHORI, A.; EBRAHIMI, G. Effect of ozone pretreatment on the physical and mechanical properties of particleboard panels made from bagasse. Measurement, v.94, p.45I-455, 2016.

KABOORANI, A.; RIEDL, B.; BLANCHET, P.; FETLIN, M.; HOSSEIMAEI, O.; WANG, S. Nanocrystalline cellulose (NCC): A renewable nano-material for polyvinyl acetate (PVA) adhesive. European Polymer Journal, v.48, n.I I, p. I829-1837, 2012.

KELLY, M.W. 1977. Critical literature review of relationships between processing parameters and physical properties of particleboard. Available at: https://www.fs.usda.gov/ treesearch/pubs/9820. Accessed in 03 December 2018.

KHAZAEIAN, A.; ASHORI, A.; DIZAJ, M.Y. Suitability of sorghum stalk fibers for production of particleboard. Carbohydrate polymers, v.120, p.15-21, 2015.

KHEDARI, J.; NANKONGNAB, N.; HIRUNLABH, J.; TEEKASAP, S. New low-cost insulation particleboards from mixture of durian peel and coconut coir. Building and environment, v.39, n. I, p.59-65, 2004.

KUMAR, A.; GUPTA, A.; SHARMA, K.V.; GAZALI, S.B. Influence of aluminum oxide nanoparticles on the physical and mechanical properties of wood composites. BioResources, v.8, n.4, p.623I-624I, 2013.

LEE, S.; MARIATTI, M. The effect of bagasse fibers obtained (from rind and pith component) on the properties of unsaturated polyester composites. Materials Letters, v. 62, n. 15, p. 2253-2256, 2008.

LEE, S.; SHUPE, T.; HSE, C. Mechanical and physical properties of agro-based fiberboard. Holz als Roh-und Werkstoff, v.64, n. I, p.74-79, 2006.

LENG, W.; HUNT, J.F.; TAJVIDI, M. Effects of density, cellulose nanofibrils addition ratio, pressing method and particle size on the bending properties of wet-formed particleboard. BioResources, v. I2, n.3, p. 4986-5000, 2017a.

LENG, W.; HUNT, J.F; TAJVIDI, M. Screw and nail withdrawal strength and water soak properties of wet-formed cellulose nanofibrils bonded particleboard. BioResources, v. 12, n.4, p.7692-77I0, 2017b.

LIU, Y.Q.; TIAN, Y.; ZHAO, G.Z. SUN Y.Y.; ZHU, F.T.; CAO, Y. Synthesis of urea-formaldehyde resin by melt condensation polymerization. Journal of Polymers Research, v. I5, n.6, p.50I-505, 2008.

LIU, Y.; ZHU, X. Measurement of formaldehyde and VOCs emissions from wood-based panels with nanomaterialadded melamine-impregnated paper. Construction and Building Materials, v.66, p.I32-I37, 2014.

LOH, Y.; SUJAN, D.; RAHMAN, M.; DAS, C. Sugarcane bagasse-The future composite material: A literature review. Resources, Conservation and Recycling, v.75, p. I4-22, 2013.
MAHRDT, E.; PINKL, S.;SCHMIDBERGER, C.; VANHERWIJNEN, H.W.; VEIGEL, S.; GINDL-ALTMUTTER, W. Effect of addition of microfibrillated cellulose to urea-formaldehyde on selected adhesive characteristics and distribution in particle board. Cellulose, v.23, p.57I-580, 2016.

MALONEY, T. The family of wood composite materials. Forest Products Journal, v. 46, n. 2, p.19-26, 1996.

MARATHE, B.; KANTAK, A. Nano additives: A Review. Paintindia, v. 58, n. 7, p. II3, 2008.

MARTINEZ, C.M.; FROLLINI, E.; CAMPANA, F.O.S. Propriedades Absorventes dos Produtos da Carboximetilação de Polpa Etanol-água de Medula de Bagaço de Cana-de-açúcar. Polímeros-Ciência e Tecnologia, v.7, n. I, p.48-57, 1997.

MARZBANI, P.; AFROUZI, Y.M.; OMIDVAR, A. The effect of nano-zinc oxide on particleboard decay resistance. Maderas Ciencia y tecnología, v. I7, n I, p.63-68, 2015.

MESQUITA, R.G.A.; CÉSAR, A.A.D.S.; MENDES, R.F.; MENDES, L.M.; MARCONCINI, J.M.; GLENN, G.; TONOLI, G.H.D. Polyester Composites Reinforced with Corona-Treated Fibers from Pine, Eucalyptus and Sugarcane Bagasse. Journal of Polymers and the Environment, v.25, p.800-8II, 2017.

MESQUITA, R.G.A.; MARCONCINI, J.M.; SANADI, A.R.; CÉSAR, A.A.D.S.; TONOLI, G.H.D.; VENÅS, T.M.; MENDES, L.M. Coir and Sisal Fibers as Fillers in the Production of Eucalyptus Medium Density ParticleboardsMDP. Materials Research, v. 19, p.|429-|436, 2016.

MESQUITA, R.G.A.; MENDES, L.M.; SANADI, A.R.; SENA NETO, A.R.; CLARO, P.I.C.; CORREA, A. C.; MARCONCINI, J.M. Urea Formaldehyde and Cellulose Nanocrystals Adhesive: Studies Applied to Sugarcane Bagasse Particleboards. Journal of Polymers and the Environment, v.26, p.3040-3050, 2018.

MME (2018). Ministério de Minas e Energia - Análise de conjuntura dos biocombustíveis, ano 2017, Brazil.

MOHANTY, A.; MISRA, M.; HINRICHSEN, G. Biofibres, biodegradable polymers and biocomposites: an overview. Macromolecular materials and Engineering, v.276, n.I, p.I-24, 2000.

NIKOLIC, M.; LAWTHER, J.; SANADI, A.R. Use of nanofillers in wood coatings: a scientific review. Journal of Coatings Technology and Research, v. I2, n.3, p.445-46I, 2015.

OLIVEIRA, S.L.; MENDES, R.F.; MENDES, L.M.; FREIRE, T.P. Particleboard panels made from sugarcane bagasse: characterization for use in the furniture industry. Materials Research, v.19, n.4, p.914-922, 2016.

RANGAVAR, H.; TAGHIYARI, H.; GHOFRANI, M.; KHOJASTEKHOSRO, S. Improving physical and mechanical properties in particleboard by recycled polyethylene and canola residues. International Journal of Environmental Science and Technology, v. 13, n.3, p.857-864, 2016. 
RASUL, M.; RUDOLPH, V.; CARSKY, M. Physical properties of bagasse. Fuel, v.78, n.8, p.905-910, 1999.

SALARI, A.; TABARSA, T.; KHAZAEIAN, A.; SARAEIAN, A. Effect of nanoclay on some applied properties of oriented strand board (OSB) made from underutilized low quality paulownia (Paulownia fortunei) wood. Journal of Wood Science, v.58, n.6, p.5I3-524, 2012.

SALARI, A.; TABARSA, T.; KHAZAEIAN, A.; SARAEIAN, A. Improving some of applied properties of oriented strand board (OSB) made from underutilized low quality paulownia (Paulownia fortunie) wood employing nano-SiO2. Industrial Crops and Products, v.42, p. I9, 2013.

SAMPATHRAJAN, A.; VIJAYARAGHAVAN, N.; SWAMINATHAN, K. Mechanical and thermal properties of particle boards made from farm residues. Bioresource technology, v.40, n.3, p.249-25I, 1992.

TAPPI (20I I). Testing Procedures of Technical Association of the Pulp and Paper industrial vol TAPPI. Atlanta, USA.

TONOLI, G.H.D.; TEIXEIRA, E.M.; CÓRREA, A.C.; MARCONCINI, J.M.; CAIXETA, L.A.; PEREIRA, M.A.S.; MATTOSO, L.H.C. Cellulose micro/nanofibres from Eucalyptus Kraft pulp: Preparation and properties. Carbohydrate Polymers, v.89, n. I, p.80-88, 2012.

UNICA (2017). AVALIAÇÃO QUINZENAL DA SAFRA 2016/20I7 DA REGIÃO CENTRO-SUL. União da Indústria de Cana-de-açúcar. http://www.unica.com.br/ documentos/documentos/. Accessed in 19 March 2017.
VEIGEL, S.; RATHKE, J.; WEIGL, M.; GINDL-ALTMUTTER, W. Particle Board and Oriented Strand Board Prepared with Nanocellulose-Reinforced Adhesive. Journal of Nanomaterials, v.20I2, p.I-8, 2012.

WHEELER, E.A.; BAAS, P.; GASSON, P.E. IAWA list of microscopic features for hardwood identification. IAWA Bull(ns), v. 10, p.219-332, 1989.

WIDYORINI, R.; XU, J.; UMEMURA, K.; KAWAI, S. Manufacture and properties of binderless particleboard from bagasse I: effects of raw material type, storage methods, and manufacturing process. Journal of Wood Science, v.5I, n.6, p 648-654, 2005.

WU, Q. Comparative properties of bagasse particleboard. In: Proceedings of the International Symposium on Utilization of Agricultural and Forest Residue. Nanjing, China, 200I. pp 277-284.

XU, X.; YAO, F.; WU, Q.; ZHOU, D. The influence of waxsizing on dimension stability and mechanical properties of bagasse particleboard. Industrial crops and products, v.29, n. I, p.80-85, 2009.

ZHANG, H.; ZHANG, J.; SONG, S.; WU, G.; PU, J. Modified nanocrystalline cellulose from two kinds of modifiers used for improving formaldehyde emission and bonding strength of urea-formaldehyde resin adhesive. BioResources, v.6, n.4, p.4430-4438, 201 I.

ZORBA, T.; PAPADOPOULOU, E.; HATJIISSAAK, A.; PARASKEVOPOULOS, K.M.; CHRISSAFIS, K. Ureaformaldehyde resins characterized by thermal analysis and FTIR method. Journal of Thermal Analysis and Calorimetry, v.92, n. I, p.29-33, 2008. 